\title{
PROPOSITIONAL GERUNDS IN ENGLISH AND SPANISH
}

\author{
Ana OJEA* \\ University of Oviedo
}

\begin{abstract}
This paper offers a characterization of Propositional Gerunds in English and Spanish that hinges on the different feature specification of the gerund morpheme in each language. I first propose an analysis of the construction in English as a defective clausal structure (AspP or TP), which can optionally project $a[+N]$ feature in a GerP. Then I justify the same syntactic analysis for Spanish, but in this case the adverbial source of the $V$-ndo head prevents the projection of this nominal feature.

My proposal is that most of the peculiarities of Propositional Gerunds in both languages actually follow from their defective structure and from the feature specification forced by the gerund suffix in each case. Along these lines I contrastively account for the syntactic positions in which a Propositional Gerund may appear, and also for its main structural characteristics, as the morphological Case of its subject or the (im)possibility of temporal/aspectual modification in the construction.
\end{abstract}

Keywords: Propositional Gerunds, defective category, grammatical feature, parametric variation, English/Spanish.

\footnotetext{
Correspondence should be sent to: Dr. Ana Ojea. Universidad de Oviedo. Depto. de Filología Anglogermánica y Francesa, Facultad de Filología Campus de Humanidades, El Milán C/ Teniente Martínez s/n 33011. Oviedo, Spain. E-mail: aojea@uniovi.es
} 


\title{
LOS GERUNDIOS PROPOSICIONALES EN INGLÉS Y EN ESPAÑOL
}

\begin{abstract}
RESUMEN. Este artículo ofrece una caracterización de los Gerundios Proposicionales en inglés y en español fundamentada en la diferencia categorial del morfema de gerundio en cada una de estas lenguas. Se propone un análisis de la construcción en inglés como una estructura oracional defectiva (TP o AspP) que puede opcionalmente proyectar un rasgo $[+N]$ en una categoría funcional GerP. Igual estructura defectiva se justifica para el español, con la diferencia de que aqui el origen adverbial del sufijo - ndo impide la proyección de ese rasgo nominal.

La propuesta concreta que defendemos es que la mayor parte de las propiedades de los Gerundios Proposicionales en las dos lenguas se sigue de su carácter sintácticamente defectivo y de su particular especificación de rasgos. Con estas premisas justificaremos las distintas posiciones sintácticas en que la construcción puede aparecer, asi como sus principales propiedades estructurales, tales como el caso morfológico de su sujeto y la (im)posibilidad de presentar modificación temporal o aspectual propia.
\end{abstract}

Palabras clave: Gerundio Proposicional, categoría defectiva, rasgo gramatical, variación paramétrica, inglés/español.

Received 8 November 2010

Revised version accepted 22 December 2010

\section{INTRODUCTION}

As is widely acknowledged, English -ing forms have a category-ambiguous nature. The following examples, adapted from Quirk et al. (1985: 1291), show their gradience from deverbal nouns to participles:

1. a. Some paintings of Brown's

b. Brown's paintings of his daughter

c. Brown's deftly painting his daughter is a delight to watch

d. I dislike Brown's painting his daughter

e. I dislike Brown painting his daughter

f. I saw Brown painting his daughter

g. Painting his daughter, Brown noticed that his hand was shaking

h. Brown painting his daughter that day, I decided to go for a walk

i. They caught Brown painting his daughter

j. The man painting the girl is Brown

$\mathrm{k}$. The silently painting man is Brown

1. Brown is painting his daughter

The morpheme -ing has a variety of functions, which go from the sheer 
nominalizer to the expression of progressive aspect. These multifunctional properties are rooted in the linguistic evolution of the form. Present day gerund is a descendant of the Old English present participle and of the verbal noun, which merged into one single form in -ing (cf. Denison 1993; Fanego 2004). From the former, it has inherited its adverbial and adjectival uses, and from the latter its nominal ones, that is, the fact that it can be used in every position which can be occupied by a DP (i.e. subject, object of the verb and object of the preposition). This double nature has also led to certain terminological indeterminacy. In traditional grammars, it is not unusual to find a distinction between the terms Gerund and Present Participle, restricting the former to the forms which have "both nominal and verbal features" and the latter to those that "don't have any nominal features, but verbal features exclusively" (Schybsbye 1965: 61). Quirk et al. (1985) systematically use the label ing-participle clause, while Huddleston and Pullum (2002) employ the general term Gerund-participial clauses for all, but both grammars distinguish those uses which can be said to be nominal from those which are not. V-ing constructions with a Genitive subject have also been termed Gerundive or Gerundival clauses (cf. Milsark 1988), and those with PRO or an Accusative subject, Clausal gerunds (cf. Johnson 1988 and Pires 2006).

In this paper I'll focus on the constructions which occupy the middle part of the list in (1), that is, those which denote states of affairs and are therefore syntactic instantiations of a proposition (1c-i), using the general term Propositional Gerunds to refer to them (henceforth, PG). I will discuss their syntactic properties and also explore the differences between these structures and the corresponding forms in Spanish. The hypothesis I would like to endorse here is that propositional gerunds have basically the same phrase structure in both languages, and that their differences just reduce to the (potentially) nominal character of the English form due to the historical sources of its -ing suffix.

As examples (1c) - (1f) show, PGs can project in argument positions normally associated to DPs, but even in these contexts the verbal nature of the -ing form is unarguably manifested in its capacity to Case-license the object, and to be modified by typical verbal adjuncts (cf. the AdvP deftly in 1c, or the temporal DP that day in 1g). But it is a fact that, despite their clausal nature, PGs differ significantly from other propositional constituents like that-clauses or to-infinitives. The syntactic status of these two is clear: they are full clauses and, as such, they may be introduced by a complementizer (that or for, respectively) and possess a complete illocutionary layer. ${ }^{1}$ This layer will minimally contain two categories (the standard term CP still being used for convenience to integrate the two): a

\footnotetext{
1 A full clause is here understood as a sentential category that comprises a thematic layer (the verbal projections, roughly vP and VP), an inflectional layer (the inflectional projections, crucially (a split) TP with independent or dependent reference), and an illocutionary layer (the discourse domain, an articulated $\mathrm{CP}$ ).
} 
category Force Phrase, which encodes the illocutionary force of the proposition and hosts a binary feature [ \pm assertion], and a category Mood Phrase, headed by the binary feature [ \pm indicative]. ${ }^{2}$ As for the difference between that-clauses and to-infinitive clauses in this respect, the former can be characterized as [ \pm assertion] and [ \pm indicative], whereas the later will be unmarkedly introduced by the features [-assertion] and [-indicative] (see Ojea 2008 for details):

$$
\begin{aligned}
& \text { 2. They said [ ForceP [+assertion] } T H A T\left[_ { \text { MoodP [+indicative] } } \left[_{\text {TP }}\right.\right. \text { SHE WAS READY AT TEN ]]] } \\
& \text { 3. They insisted [ } \text { Forcep [-assertion] }_{\text {THAT }} \text { MoodP [-indicative] }_{\text {TP }} \text { SHE BE READY AT TEN ]]] } \\
& \text { 4. I'd prefer [ }{ }_{\text {Forcep [-assertion] }} \text { FOR [ } \text { MoodP [-indicative] }_{\text {TP }} \text { HER TO BE READY AT TEN ]]] }
\end{aligned}
$$

Turning now to PGs, they tend to be grouped with to-infinitives as non-finite sentences, but there is enough empirical evidence to support that they don't have the same constituent structure: thus, contrary to to-infinitive clauses, PGs can be introduced by both [ \pm assertive] predicates (5), are not associated with a complementizer (6) and can never be introduced by an interrogative phrase (7):

\section{I remember/suggested going there \\ 6. He remembers *that/*for going there \\ 7. *He remembers where going}

PGs, then, might be said to lack a CP layer, that is, they are defective clausal categories without an illocutionary shell and, therefore, unmodalized. This in turn serves to explain some of the semantic differences between to-infinitive complements and PGs after certain predicates: in general, to-infinitives convey a meaning of potentiality (given the illocutionary features that introduce them and the modal reading of the particle to), whereas PGs refer to actualised situations. ${ }^{3}$

\footnotetext{
2 The feature [ \pm assertion] alludes to the speaker's degree of commitment to the proposition in terms of asserting it or, alternatively, expressing some inquiry, suggestion, order... In Rizzi's seminal account of the left periphery of the clause in English (cf. Rizzi 1997), it is assumed that CP splits into Force Phrase and Finite Phrase, the latter signalling the (non) finiteness of the clause. My analysis here uses MoodP instead of Finite Phrase, since a mere look at languages morphologically richer than English (for example, Spanish) shows that the (non) assertive nature of the clause ultimately conditions its grammatical mood; that is, I believe that a category MoodP qualifies as a more natural complement of ForceP than Rizzi's FiniteP.

3 In contexts where to-infinitives and PGs are syntactic alternatives, for example after emotive predicates such as like, love, hate or prefer, the implication follows that PGs will be used to express general preferences (i), whereas the infinitive option will be selected in constructions like (ii), where the modal auxiliary would favours a sense of potentiality (cf. Quirk et al. 1985)

i) I love going/to go out with you

ii) I'd like to go out / *going out with you
} 
Assuming then that PGs are defective clausal structures (with no CP), their internal structure will just comprise: a) an inflectional layer that contains a Tense projection and a category AspP with a [-perfective] feature, and b) a thematic layer with a vP, where the external argument of the verb (and prospective subject of the sentence) sits, and a VP, where the internal arguments are projected:

\section{8. $\mathrm{I}_{\mathrm{TP}}[+$ person $] \mathrm{T}\left[_{\text {AspP }} \operatorname{Asp}_{[- \text {perfecive }]}\left[_{\mathrm{VP}}\right.\right.$ Subject $\mathrm{v}\left[_{\mathrm{VP}} \mathrm{V}\right.$-ing Object $\left.\left.\left.]\right]\right]\right]$}

Here I'll argue that PGs can project up to TP or just up to AspP and that, given the sources of the suffix -ing in English, they can also merge with a functional category GerP that acts as a nominalizer (cf. Panagiotidis and Grohmann 2005). With this analysis I seek to explain some of the defining formal properties of the construction, such as the possibility for it to be an argument or an adjunct of the matrix predicate, or the Case of its subject (Null, Accusative, Genitive or Nominative).

Section 2 explores the structure of argument PGs in English, that is, those PGs that appear in subject or object position. Section 3 analyzes adjunct PGs, and Section 4 extends the analysis to Spanish PGs with a double-folded goal: to provide empirical support for some of the assumptions in the previous sections, and to systematize the differences among the PGs in the two languages in terms of their feature-checking requirements (ultimately related to their different linguistic origin). In section 5, I present my conclusions.

\section{ARGUMENT PGS IN ENGLISH}

PGs not only differ from full clauses in their syntactic structure but also in their distribution. For example, when full clauses appear as the subject of a sentence: ${ }^{4}$

a) They do not invert with the auxiliary in direct questions:

9. a. That John came surprised everybody

b. *Did that John came surprise everybody?

10. a. For you to abandon the job surprised everybody

b. *Did for you to abandon the job surprise everybody?

b) they can be extraposed from the subject position:

11. a. It surprised everybody that John came

b. It surprised everybody for you to abandon the job

\footnotetext{
Note also the different readings obtained, in this sense, after verbs like try or intent:

iii) He tried going to bed early (=actual fact) vs He tried to go to bed early (=attempt)

4 The examples from (9) to (11) have been taken from Haegeman and Guéron (1999: 114), and those in (12) and (13) from Huddleston (1988: 63).
} 
c) They cannot be the subject of a small clause unless under extraposition:

12. a. *I consider that he will abandon the job unimportant

b. I consider it unimportant that he will abandon the job

13. a. *This made to accompany them a waste of time

b. This made it a waste of time to accompany them

(Full) clausal subjects, then, behave quite differently from DP subjects, and this has led to the proposal that they do not in fact occupy the canonical subject position (i.e. that they do not sit in (Spec, TP)), but in a non-argumental position above it (see Haegeman and Guéron 1999 and references therein). I will not pursue this issue further here, but I'd like to point out that, significantly, PGs contrast with full clauses precisely in the three contexts above, that is:

a) They invert with the auxiliary in direct questions when they are the subject of the main sentence:

14. Does her being a solicitor matter very much?

b) They cannot be extraposed from the subject position:

15. *It matters very much ber being a solicitor

c) They can be the subject of a small clause:

16. She considered attempting it a waste of time

Clearly, PGs align with DP subjects in this respect, and not with full clauses. The same situation holds for the position of complement of a preposition, which is forbidden to full clauses but, as expected, allows for PGs:

17. Mary escaped before ${ }^{*}{ }_{\mathrm{CP}}$ to tell the story $]$

18. Mary escaped before ${ }^{*}\left[{ }_{\mathrm{CP}}\right.$ that she told the story $]$

19. Mary escaped before $\left[_{\mathrm{TP}}\right.$ she told the story]

20. Mary escaped before $\left[_{\mathrm{TP}}\right.$ telling the story]

This DP-like distribution must result from some peculiarity in the syntactic structure of PGs, and there have been varied attempts in the generative tradition to characterize it (cf. Wasow and Roeper 1972, Horn 1975, Akmajian 1977, Stowell 1982, Reuland 1983, Baker 1985, Abney 1987, Milsark 1988 and Pires 2006, among others, for specific proposals). I adhere here to the view defended by Panagiotidis and Grohmann (2005) which sees argument PGs (cf. examples 1c-f above) as mixed categories with a clausal/verbal layer and a SWITCH that nominalizes the projection and that they call GerP. GerP bears an uninterpretable verbal feature that has to be checked against the interpretable verbal feature of the V-ing form, and, most significantly, an interpretable $[+\mathrm{N}]$ feature that guarantees the nominal 
behaviour of the category since it forces an uninterpretable Case feature in the projection that will have to be valued in one of the positions accessible to Case valuation (i.e. subject or object position).

One of the most salient properties of these argument PGs is the fact that they may allow for a covert subject (canonically, PRO) or for a lexical subject in the Accusative or the Genitive Case. Consider, in this respect, the following examples:

21. I won't risk PRO/him/his going alone to that place

22. I would suggest $\mathrm{PRO} / \mathrm{him} /$ his getting up earlier

23. I hate $\mathrm{PRO} / \mathrm{him} / \mathrm{his}$ reading poems aloud

24. I remember $\mathrm{PRO} / \mathrm{him} / \mathrm{his}$ singing in that party

From Horn (1975) it is customary to distinguish among PRO-ing, Acc-ing and Poss-ing clauses, and there appears to be a considerable variation among speakers of English in their judgement of the three morphological possibilities. But, in general, Poss-ing is seen as more DP-like than the other two, and this is why Panagiotidis and Grohmann (2005) treat this construction as a fully nominalized clause that projects a DP-layer over GerP and licenses a Genitive subject there. The (simplified) phrase marker of a Poss-ing clause will then be:

25. I hate $\left[_{\mathrm{DP}}\right.$ his $\mathrm{D}_{[\mathrm{GEN}]}\left[_{\mathrm{GerP}} \operatorname{Ger}_{[+\mathrm{N}][\mathrm{uV}]}\left[_{\mathrm{TP}}\right.\right.$ his $\left[_{\mathrm{AspP}} \operatorname{Asp}_{[- \text {perfective }]}\left[_{\mathrm{VP}}\right.\right.$ his reading ${ }_{[+\mathrm{V}]}$ poems aloud]]]]

The derivation in (25) is convergent since the verb reading can check the uninterpretable $[\mathrm{uV}]$ feature in the head of GerP, and the subject of the PG, his, unmarkedly values its Genitive case in (Spec,DP). The nominal feature in GerP, in turn, ensures that the construction will only be found in Case sensitive positions.

As for PRO-ing or Acc-ing clauses, they still have a nominalizer GerP but lack the dominating DP projection and, accordingly, the capacity to license a Case for the subject different from the standard options in untensed sentences, that is Null Case or Accusative after certain ECM predicates, as risk, suggest, hate or remember above:

26. I hate $\left[_{\text {GerP }} \operatorname{Ger}_{[+\mathrm{N}][\mathrm{uV}]}\left[_{\mathrm{TP}}\right.\right.$ him/PRO T $\left[_{\mathrm{AspP}} \operatorname{Asp}_{[- \text {perfective }]}\left[_{\mathrm{vP}}\right.\right.$ him/PRO reading ${ }_{[+\mathrm{V}]}$ poems aloud]]]

The peculiarities of argument PGs in English can then arguably follow from their status as mixed categories with a GerP whose $[+\mathrm{N}]$ feature determines its distribution, and an optional DP that accounts for the Case variability of the subject. Since the complement of GerP is a TP, the rest of the properties of 
the construction follow from standard assumptions. Thus, there will be an EPP requirement (codified in a [+person] feature in the specifier of TP) that forces the projection of an expletive when no other subject is available:

27. He bothered about there being few people present

And, since they have a Tense-chain, they will allow for the sentential negation not (28), or for the aspectual auxiliaries have and be (understood as modifying elements inside the T-chain; cf. Gueron and Hoekstra 1995) as in (29):

28. Not selling the house now will be rather problematic for him

29. His having abandoned his daughter caused a great commotion

Finally note that the nucleus of the T-chain is a Tense operator distinct from the matrix Tense operator but dependent on it; the time interval of the argument PG will then be constrained by the meaning of the main verb and the temporal information of the matrix sentence: ${ }^{5}$

30. I perfectly remember locking the door as I left the house (PG anterior to matrix predicate)

31. Mary worried yesterday about coming to dinner tonight (PG posterior to matrix predicate)

32. Brown hates walking in the city at night (PG coincident with matrix predicate)

Propositional gerunds can also be productively found in English as complements of perception verbs:

33. I smelled [Hank spreading the mud] (I didn't necessarily smell Hank)

34. We heard [the farmer slaughtering the pig] (We didn't necessarily heard the farmer)

These examples (from Dik and Hengeveld 1991: 253) strongly support the standard analysis of this construction in terms of complement selection of a proposition and not of an individual, since their interpretation shows that the DP (Hank or the farmer) is not the entity directly perceived but a participant of the -ing predicate. This is even clearer in examples as (35), since expletive it cannot but be the subject of the PG with the meteorological verb rain:

\footnotetext{
5 The example in (31) has been taken from Pires (2006: 71).
} 


\section{I saw [it raining]}

The complements of perception verbs will then be PGs with a lexical subject, but these PGs exhibit some significant differences with respect to the other argument PGs analysed so far. In particular, they do not allow for aspectual auxiliaries or any temporal modification of their own (36) and exclude non Accusative subjects (37):

\section{6. *I saw Peter having closed the door}

37. *I saw PRO/Peter's closing the door

Given these restrictions, these PGs can not be treated syntactically as ordinary (nominalized) TPs, even though semantically they resemble clauses and show a conventional subject-predicate relationship. I'll suggest that they constitute what has been termed a small clause, a type of construction which has been the focus of significant attention in the generative literature. ${ }^{6}$

From the seminal work of Stowell (1981), it has been standardly assumed that the two constituents of the small clause denote closed propositions, and that they project a category headed by the predicate. ${ }^{7}$ A point of controversy among those who admit this constituent structure is whether small clauses are just the projection of a lexical head or should be introduced by a functional category, and, if the latter holds, what particular category it is. Significantly, it has been noted in this respect that what the matrix predicate selects in its small clause complement is not the syntactic category of the predicate but its aspectual features. ${ }^{8}$ This would lead to the assumption that small clauses are dominated by an AspP projection whose head features are selected by the matrix predicate and need to be valued by the subordinate one.

If the PGs found in the complement position of perception verbs are small clauses, they can be said to exhibit an extra degree of defectiveness from the ones explored above (i.e. they are not only CP defective, but also TP defective), and this may well explain the differences between them. Their analysis will schematically be as in (38):

\footnotetext{
${ }_{6}$ The label "small clause" has been employed in the generative tradition to refer to the smallest propositional projection, that is, the one consisting of just a predicate with its subject.

7 For an alternative view, see Williams (1983).

8 For example, in the case of adjectival small clauses, certain verbs, such as judge, select individual level predicates whereas the complement predicate in others, such as expect, can only be stage level:

i) Mary judged him intelligent / "bad tempered

ii) Mary expected him *intelligent / bad tempered

For an analysis of small clauses along these lines see, among others, Kitagawa 1985, Hernanz 1988, Demonte 1991, Jiménez 2000 and references therein.
} 
38. $\mathrm{V}_{\text {perception }}\left[\mathrm{GerP} \operatorname{Ger}_{[+\mathrm{N}][\mathrm{uV}]}\left[_{\mathrm{AspP}} \operatorname{Asp}_{[- \text {perfective }]}\left[{ }_{\mathrm{VP}} \mathrm{DP}\right.\right.\right.$ V-ing]]]

Since there is no TP, there will not be a T-chain either and, accordingly, no aspectual auxiliaries (cf. 36). As regards the Case of the subject, it must be Accusative (cf. 37) since it is valued in the domain of the inner VP shell of the transitive matrix predicate under ECM conditions.?

Finally, note that this analysis of the complements of perception verbs as small clauses predicts that the matrix predicate can select the feature [-perfective] on AspP (as in (33)-(35)), or alternatively, the value [+ perfective], the contrast between PGs and bare infinitive clauses stemming from this option:

39. I saw [ ${ }_{\text {GerP }} \operatorname{Ger}_{[+\mathrm{N}][\mathrm{uV}]}\left[\mathrm{AspP}_{\text {Asp }} \operatorname{Asp}_{[-\mathrm{imp}]}\right.$ [VP $_{\mathrm{VP}}$ Peter closing the door]]] I saw $\left[_{\text {GerP }} \operatorname{Ger}_{[+\mathrm{N}][\mathrm{uV}]}\left[_{\mathrm{AspP}} \operatorname{Asp}_{[+\mathrm{imp}]}\left[{ }_{\mathrm{VP}}\right.\right.\right.$ Peter close the door]]]

\section{ADJUNCT PGS IN ENGLISH}

PGs can also appear as in positions excluded to DPs, as adjuncts of the matrix predicate (cf. 1 g-i above). As argued, they will be TP or AspP depending on their degree of defectiveness but they will differ from argument PGs in that they don't have a $[+\mathrm{N}]$ feature in their phrase marker, and, accordingly, don't project a GerP (or a DP).

When they are non-integrated, they are TPs since they can display the sentential negation (40) and have their own temporal/aspectual modification (41): ${ }^{10}$

40. $\left[_{\mathrm{TP}} \mathrm{PRO}^{\alpha}\right.$ not knowing the answer], John ${ }^{\alpha}$ felt at a loss

41. $\left[_{\mathrm{TP}} \mathrm{PRO}^{\alpha}\right.$ having left the room], Tom ${ }^{\alpha}$ was acclaimed by everybody

And, since their Tense-chain is external to that of the main clause, their time reference is independent from that of the main predicate and can be simultaneous, anterior or posterior to it (cf. 42, 43 and 44, respectively): ${ }^{11}$

42. Peter $^{\alpha}$ had been present during the recording, $\mathrm{I}_{\mathrm{TP}} \mathrm{PRO}^{\alpha}$ relaying instructions to the presenter]

43. ${ }_{\mathrm{TP}} \mathrm{PRO}^{\alpha}$ closing the door], he ${ }^{\alpha}$ disappeared into the night

\footnotetext{
9 This ECM behaviour (common to all small clauses) is confirmed by the fact that the subject of the PG will raise to the subject position of the main clause when the matrix verb is passive (and therefore unable to license Acc case): Peter was heard singing.

${ }^{10}$ Example (40) is from Guéron and Hoekstra (1995: 95).

${ }^{11}$ Anteriority in non-finite clauses is customarily signalled with the auxiliary have (cf. 41); if this is not present, only a reading of immediate anteriority will be possible.
} 
44. She ${ }^{\alpha}$ closed the book, $\left[_{\mathrm{TP}} \mathrm{PRO}^{\alpha}\right.$ leaving it on the table]

As for the Case of the subject in these non-integrated PGs, the prediction is that it cannot be Genitive (since no DP layer is projected) or Accusative (there is no ECM configuration), and therefore, that only Null Case, the one unmarkedly validated in non-finite clauses, will be possible here (compare with the options in (21)-(24)):

45. $\left[_{\mathrm{TP}} \mathrm{PRO}^{\alpha} /\right.$ *John's / *Him having left the room], Tom ${ }_{\alpha}$ was acclaimed by everybody

But in this configuration it is also possible to find a lexical subject in the Nominative Case, something unexpected under the current theory which links Nominative Case to morphological finiteness in Tense (cf. 1h): ${ }^{12}$

46. $\left[_{\mathrm{TP}}\right.$ His hands gripping the door], he let out a volley of curses.

47. Elaine's winking at Roddy was fruitless, $\left[_{\mathrm{TP}}\right.$ he being a confirmed bachelor]

I would like to assume, following López (1994), that non-integrated sentential modifiers can have an uninterpretable strong feature [+absolute] in $\mathrm{T}$, a feature which formalizes the distinction in traditional grammars between "free adjuncts" and "absolute constructions" (cf. Kortmann 1991). This feature triggers overt movement of the verb to $\mathrm{T}$ and licenses a Nominative-bearing DP in (Spec, TP). This possibility seems to be implicitly connected to the fact that the tense operator that heads the Tense-chain in these constructions is independent from that of the matrix predicate; it thus patterns with standard tensed clauses in this respect and, accordingly, allows for the same Case feature (Nominative) in its specifier:

48. A $\mathrm{T}_{[+ \text {Absolute] }}$ may license a Nominative Case in its Spec

Note that only non-finite sentential categories projected in a non-integrated position (i.e. outside the scope of the matrix predicate) will display this [+absolute] feature and, with it, the capacity to license a Nominative subject. Therefore, a Nominative subject will never be found in to-infinitive sentences, given that they cannot appear in these positions in English; on the contrary, non-integrated pastparticle clauses will pattern with PGs in this respect: (e.g. The dinner finished, they went to a different room). These facts strongly suggest that Nominative Case should be linked to independent temporal reference, and not exclusively to finiteness.

${ }^{12}$ Example (46) has been taken from Huddleston et al. (2002: 1265) and (47) from Reuland (1983: 101). 
Finally PG adjuncts may also function as subject/object predicatives that is, as adjuncts integrated in the main clause as a secondary predication referring either to the subject or to the object:

49. He came in [greeting everybody]

50. Ed caught the guard [beating the prisoner]

As in the case of the complement of perception verbs, my proposal is that the PGs in (49)-(50) are TP-defective, that is, they are small clauses and thus only project up to AspP, as represented in (51) and (52):

51. $\mathrm{He}^{\alpha}$ came in $\left[_{\mathrm{AspP}} \mathrm{Asp}_{\text {[-perfective] }}\left[_{\mathrm{VP}} \mathrm{PRO}^{\alpha}\right.\right.$ greeting everybody]

52. Ed caught the guard ${ }^{\alpha}\left[_{\mathrm{AspP}} \operatorname{Asp}_{\text {[-perfective }]}\left[_{\mathrm{VP}} \mathrm{PRO}^{\alpha}\right.\right.$ beating the prisoner]

As expected, these PGs do not allow for aspectual auxiliaries or any temporal modification of their own (since they lack a TP-chain; see (53)), and cannot license a lexical subject either, the empty pronominal PRO (co-referent to the subject or the object of the main sentence) being the only option here (cf. 54):

53. *He came in [having greeted everybody]

54. He came in [PRO / *his wife's / *his wife greeting everybody]

Recapitulating so far, I have shown that the main properties of PGs in English follow from their particular phrase structure (i.e. as defective clausal structures up to AspP or TP), and from the grammatical features that they project in the functional category GerP when they appear in argument positions. Figure (55) summarizes the different options:

55. PGs in English

\begin{tabular}{|c|c|c|c|}
\hline TP & PHRASE MARKER & SUBJECT IN THE PG & T-CHAIN \\
\hline Argument & 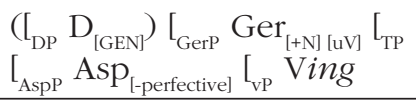 & $\begin{array}{l}\text { Genitive/Accusative/ } \\
\text { Null }\end{array}$ & Dependent \\
\hline $\begin{array}{l}\text { Non-integrated } \\
\text { adjunct }\end{array}$ & $\begin{array}{l}\mathrm{L}_{\mathrm{TP}} \mathrm{T}_{(\text {I }+ \text { absolute })} \mathrm{C}_{\mathrm{AspP}} \mathrm{Asp}_{\text {[-perfec- }} \\
\text { tive] } \\
\mathrm{vPP}_{\mathrm{vP}} \text { Ving }\end{array}$ & Null/ Nominative & Independent \\
\hline
\end{tabular}




\begin{tabular}{|c|c|c|c|}
\hline AspP & PHRASE MARKER & SUBJECT IN THE PG & T-CHAIN \\
\hline Argument & $\begin{array}{l}{\left[_{\text {GerP }} \operatorname{Ger}_{[+\mathrm{N}][\mathrm{LuV}]} \mathrm{C}_{\mathrm{AspP}} \mathrm{Asp}_{[- \text {perfective] }}\right.} \\
\text { [ }_{\mathrm{vP}} \text { Ving }\end{array}$ & Accusative (ECM) & \\
\hline $\begin{array}{l}\text { Integrated } \\
\text { adjunct }\end{array}$ & $\mathrm{f}_{\text {AspP }} \operatorname{Asp}_{\text {[-perfective] }} \mathrm{L}_{\mathrm{vP}}$ Ving & Null & - \\
\hline
\end{tabular}

Syntactic defectiveness defines the construction as such, because PGs are non-finite structures which differ from full clauses in quite evident ways. But the possibility to be introduced by a nominalizer GerP is clearly a language particular property related to the historical development of the V-ing form, whose origin as a verbal noun has conferred it certain nominal properties canonically absent from verbs. Expectedly the category GerP will not be found in the gerund forms of a language diachronically different from English. This is the case of Spanish, and, as I'll show, most of the differences between the two languages in the construction follow from this particular difference in their phrase structure.

\section{PGS IN SPANISH}

Spanish gerund form V-ndo comes from the Oblique Case (Ablativo) of a verbal form in Latin, and thus has always had an adverbial nature (cf. Bassols De Climent 1992). Therefore, the gerund suffix in Spanish will never project a functional category GerP with a $[+\mathrm{N}]$ feature and, accordingly, PGs here will not be found in argument position. The options in Spanish will then be reduced to:

56. PGs in Spanish

\begin{tabular}{|l|l|c|c|}
\hline \multicolumn{1}{|c|}{ TP } & \multicolumn{1}{|c|}{ PHRASE MARKER } & SUBJECT IN THE PG & T-CHAIN \\
\hline $\begin{array}{l}\text { Non-integrated } \\
\text { adjunct }\end{array}$ & $\begin{array}{l}\mathrm{f}_{\mathrm{TP}} \mathrm{T}_{\text {(I+absolute] })}\left[_{\text {AspP }} \text { Asp }\right. \\
\mathrm{V}_{\mathrm{vP}} \text { Vndperfective] }\end{array}$ & Null/ Nominative & Independent \\
\hline
\end{tabular}

\begin{tabular}{|l|l|l|l|}
\hline \multicolumn{1}{|c|}{ AspP } & \multicolumn{1}{|c|}{ PHRASE MARKER } & SUBJECT IN THE PG & T-CHAIN \\
\hline $\begin{array}{l}\text { Integrated } \\
\text { adjunct }\end{array}$ & $\mathrm{f}_{\mathrm{AspP}}$ Asp [-perfective] $_{\mathrm{vP}}$ Vndo & Null & - \\
\hline
\end{tabular}

When adjunct PGs project up to TP in Spanish, they function as external modifiers of the matrix predicate, licensing Null Case in the subject position: 
57. $\mathrm{PRO}^{\infty}$ yendo para casa, Juan $^{\infty}$ se encontró con su vecina

As in the corresponding cases of English, being a TP, the construction can display the sentential negation no:

58. No sintiéndose apoyado, decidió abandonar

Besides, being a non-integrated modifier, its Tense-chain is external to that of the main clause; this means that its time reference is independent from that of the main predicate, and, as in English, can be simultaneous or immediately anterior to it:

59. Sonriendo, María se acercó a la ventana

60. Cerrando la puerta, Juan desapareció en la noche

But, as (61) shows, contrary to English, a reading of posteriority seems to be totally impossible in Spanish (cf. Bello 1981: 322):

\section{1. *Juan cerró el libro, dejándolo sobre la mesa}

One should note in this respect that this is not a restriction particular to the construction but connected to the impossibility for suffix -ndo to signal future in any context, not even in analytical progressive forms (cf. *El tren está saliendo a las doce). ${ }^{13}$

Non-integrated PGs in Spanish can also display a [+absolute] feature in $\mathrm{T}$, thus licensing, as in English, a Nominative subject. In these constructions the order in Spanish is VS and not SV, but, once again, this difference is not particular to the construction but has to do with a parametric distinction between the two languages, probably related to the feature [+person] in the specifier of TP, which is weak in Spanish and thus checked in the covert Syntax (i.e. after Spell Out): ${ }^{14}$

62. Faltando Juan, la fiesta resultaría aburrida

63. Llegando María, todos se callan

\footnotetext{
${ }^{13}$ A future reading is nevertheless possible in non-progressive imperfective forms in Spanish:

i. El tren sale mañana a las doce.

ii. Mañana tocaban en Madrid, pero el concierto se suspendió.

14 See Ortega Santos (2008) for a detailed account of the differences between English and Spanish in the projection of the subject.
} 
In Spanish there also exist sentences which closely resemble (33)-(35) above:

\section{Vi a Pedro cerrando la puerta}

Since I argued there that, after perception verbs, PGs in English are small clauses (AspP) introduced by a GerP with a [+N] feature, sentences like (64) seem to challenge my assumption that the $\mathrm{V}-n d o$ form in Spanish never projects a nominal feature. But there is reason to believe that (64) does not have the same structure that its counterpart in English whose analysis, repeated here for convenience, was:

65. I saw $\left[_{\text {GerP }} \operatorname{Ger}_{[+\mathrm{N}][\mathrm{uV}]}\left[_{\mathrm{AspP}} \operatorname{Asp}_{[- \text {perfective }]}\left[_{\mathrm{VP}}\right.\right.\right.$ Peter closing the door]]

The assumption was that the complement of the perception verb saw was the state of affairs Peter closing the door and that the PG contrasted here with the bare infinitive only in aspectual terms (cf. I saw Peter close the door). But in (64) what is perceived is not the activity, but the entity Pedro at the time when he was in the middle of the activity. Therefore, in this construction the perception verb selects an individual as its complement and not a proposition, which means that the V-ndo complement must be treated here, as expected, as a non-nominal category, i.e. as a predicative adjunct as those analysed in (49)-(50) for English:

66. Vi a $\operatorname{Pedro}^{\alpha}\left[_{\mathrm{AspP}} \operatorname{Asp}_{\text {[-perfective }]}\left[\mathrm{VRO}^{\alpha}\right.\right.$ cerrando la puertal]

Some empirical facts argue for this different constituent structure after perception verbs in Spanish. Consider (67) and (68):

67. *Vi lloviendo

68. *Vi todo mi optimismo desapareciendo

As represented in (66), the verb ver needs a referential DP (the perceived entity) in its complement position. In (67) there is no DP, and the event llover by itself cannot qualify as the object of the verb (note the contrast with the corresponding example in English: I saw it raining); as for sentence (68), the ungrammaticality results from the features of the object DP, which is abstract and, therefore, not the perceivable entity the verb requires. ${ }^{15}$

\footnotetext{
${ }^{15}$ Actually, when the object of a perception verb in Spanish is intended to be a particular state of affairs, and not an entity, a full clause (i.e. a finite clause or an infinitive complement), must be used; this is why, contrary to (67) and (68), the following examples are grammatical:

i. Vi que llovía / llover

ii. Vi que mi optimismo desaparecía / desaparecer mi optimismo
} 
Adjunct predicative PGs in Spanish are then TP-defective and project only up to AspP. They can refer to the object as in (64) or to any other argument in the matrix sentence, as the subject in (69) or the prepositional complement in (70) (examples taken from RAE, 2009: 2043), and since they do not project a TP, they will not allow for aspectual auxiliaries or any temporal modification of their own (cf. 71):

69. Llegó llorando

70. A veces pienso en él fumándose un enorme puro

71. *Llegó habiendo llorado

\section{CONCLUDING REMARKS}

I have claimed here that under the common term Propositional Gerund one can find a number of different structures, all of which denote states of affairs and are syntactically defective. They project up to TP or just AspP, and arguably many of the formal properties of the construction follow from this degree of defectiveness. This is common to both Spanish and English PGs and explains their striking similarities in structural terms.

But the double nature of suffix -ing in English as a result of its historical origins allows for a type of nominalized PGs in this language which are found in argument positions and contrast significantly with full clauses there. They constitute mixed projections where the TP or AspP category merges with a GerP (and optionally with a DP) whose $[+\mathrm{N}]$ feature forces an uninterpretable Case feature that has to be valued in a Case-licensing configuration, that is, in subject or object position. Spanish PGs, on the contrary, will never project this $[+\mathrm{N}]$ feature (or the GerP associated to it), and this explains the main differences between the two languages, namely the fact that Spanish PGs will never be found in argument positions and that they will never have an Accusative or Genitive subject.

It has been frequently argued (cf. Liceras et al. 2008) that success or failure in L2 acquisition hinges crucially on the ability to acquire functional categories, features and feature strength different from those present in the L1 grammar. If this is so, my approach to PGs in English and Spanish may have contributed to isolate the few properties of the construction which are language specific, thus paving the way for a pedagogically appropriate account of them for L2 learners.

\section{REFERENCES}

Abney, S. 1987. The English Noun Phrase and its Sentential Aspect. PhD Thesis. Cambridge, Mass.: MIT. 
Akmajian, A. 1977. "The complement structure of perception verbs in an autonomous syntax framewok". In P.W. Culicover, T. Wasow and A. Akmajian (eds.). Formal Syntax. New York: Academic Press. 427-460.

Baker, M. 1985. "Syntactic affixation and English gerunds". Proceedings of the West Coast Conference on Formal Linguistics 4. Stanford CA: Stanford Linguistics Association. 1-11.

Bassols De Climent, M. 1992. Sintaxis Latina. Consejo Superior de Investigaciones Científicas.

Bello, A. 1981 (1847). Gramática de la lengua castellana destinada al uso de los americanos. Ed. Crítica de R. Trujillo. Tenerife: Aula de Cultura de Tenerife.

Chomsky, N. 1995. The Minimalist Program. Cambridge, MA: The MIT Press.

Demonte, V. 1991. Detrás de la palabra. Estudios de Gramática del Español. Madrid: Alianza Universidad.

Denison, D. 1993. English Historical Syntax. Longman: London.

Dik, S. and K. Hengeveld. 1991. "The hierarchical structure of the clause and the typology of perception-verb complements". Linguistics 29: 231-259.

Fanego, T. 2004. "On reanalysis and actualization in syntactic change: the rise and development of English verbal gerunds". Diachronica 21 (1): 5-55.

Guéron, J. and T. Hoekstra. 1995. "The temporal interpretation of predication". Syntax and Semantics 28. Small Clauses. Eds. A. Cardinaletti and M.T. Guasti. New York: Academic Press.

Haegeman, L. and J. Guéron. 1999. English Grammar. Oxford: Blackwell.

Hernanz, M.L. 1988. "En torno a la sintaxis y la semántica de los complementos predicativos en español". Estudi General 8: 7-29.

Horn, L. 1975. "On the nonsentential nature of the POSS-ING construction". Linguistic Analysis 1 (4): 333-387.

Huddleston, R. 1988. English Grammar. An outline. Cambridge: Cambridge University Press.

Huddleston, R., and G. K. Pullum 2002: The Cambridge Grammar of the English Language. Cambridge: Cambridge University Press.

Jiménez, A. 2000. "Rasgos aspectuales y categoriales en las cláusulas sintéticas: variación paramétrica en inglés y en español”. Atlantis 22 (1): 31-46.

Johnson, K. 1988. "Clausal gerunds, the ECP, and government". Linguistic Inquiry 19 (4): 583-609.

Kitagawa, Y. 1985. "Small but clausal". Chicago Linguistic Society 21: 210-220.

Kortmann, B. 1991. Free Adjuncts and Absolutes in English. London: Routledge. 
Liceras, J.M., H. Zobl and H. Goodluck (eds.). 2008. The Role of Formal Features in Second Language Acquisition. New York: Lawrence Erlabaum Associates.

López, L. 1994. "The internal structure of absolute small clauses". Catalan Working Papers in Linguistics 4 (1): 45-92.

Milsark G. L. 1988. "Singl-ing". Linguistic Inquiry 19 (4): 611-634.

Ojea, A. 2008. "A feature analysis of to-infinitive sentences". Atlantis 30 (1): 69-83.

Ortega Santos, I. 2008. Projecting Subjects in Spanish and English. PhD thesis. University of Maryland.

Pires, A. 2006. The Minimalist Syntax of Defective Domains. Amsterdam: John Benjamins.

Quirk, R., S. Greenbaum, G. Leech, and J. Svartvik. 1985: A Comprehensive Grammar of the English Language. London: Longman.

Real Academia Española 2009. Nueva Gramática. El español de todo el mundo. Madrid: Espasa.

Reuland, E. 1983. "Governing -ing". Linguistic Inquiry 14 (1): 101-136.

Rizzi, L. 1997. "The Fine Structure of the Left Periphery". Elements of Grammar. Ed. L. Haegeman. Dordrecht: Kluwer.

Schybsbye, K. (1965): A Modern English Grammar. Oxford: Oxford University Press

Stowell, T. 1981. Origins of Phrase Structure. PhD Thesis. Cambridge, Mass: MIT

Stowell, T. 1982. "The tense of infinitives". Linguistic Inquiry 13 (4): 561-570.

Wasow, T. and T. Roeper. 1971. "On the Subjects of Gerunds". Foundations of Language, 8: 44-61.

Williams, E. 1983. "Against Small Clauses”. Linguistic Inquiry 14: 287-308. 